Temporal changes in physical, chemical and biological sediment parameters in a tropical estuary after mangrove deforestation

Ellegaard, Marianne; Nguyen, Ngoc Tuong Giang; Andersen, Thorbjørn Joest; Michelsen, Anders; Lam Nguyen, Ngoc; Hai Doan, Nhu; Kristensen, Erik; Weckström, Kaarina; Phuoc Hoang Son, Tong; Lund-Hansen, Lars Chresten

Published in:

Estuarine, Coastal and Shelf Science

DOI:

10.1016/j.ecss.2014.03.007

Publication date:

2014

Document version

Early version, also known as pre-print

Citation for published version (APA):

Ellegaard, M., Nguyen, N. T. G., Andersen, T. J., Michelsen, A., Lam Nguyen, N., Hai Doan, N., Kristensen, E., Weckström, K., Phuoc Hoang Son, T., \& Lund-Hansen, L. C. (2014). Temporal changes in physical, chemical and biological sediment parameters in a tropical estuary after mangrove deforestation. Estuarine, Coastal and Shelf Science, 142, 32-40. https://doi.org/10.1016/j.ecss.2014.03.007 


\title{
Temporal changes in physical, chemical and biological sediment parameters in a tropical estuary after mangrove deforestation
}

\author{
Marianne Ellegaard ${ }^{\mathrm{a}, \mathrm{d}, *}$, Ngoc Tuong Giang Nguyen ${ }^{\mathrm{b}, \mathrm{d}}$, Thorbjørn Joest Andersen ${ }^{\mathrm{c}}$, \\ Anders Michelsen ${ }^{\mathrm{d}}$, Ngoc Lam Nguyen ${ }^{\mathrm{b}}$, Nhu Hai Doan ${ }^{\mathrm{b}}$, Erik Kristensen ${ }^{\mathrm{e}}$, \\ Kaarina Weckström ${ }^{\mathrm{f}}$, Tong Phuoc Hoang Son ${ }^{\mathrm{b}}$, Lars Chresten Lund-Hansen ${ }^{\mathrm{g}}$ \\ ${ }^{a}$ Department of Plant and Environmental Sciences (PLEN), University of Copenhagen, Thorvaldsensvej 40, 1st Floor, DK-1871 Frederiksberg C, Denmark \\ ${ }^{\mathrm{b}}$ Institute of Oceanography, Vietnam Academy of Science and Technology, Nha Trang, Viet Nam \\ ${ }^{\mathrm{c}}$ Department of Geosciences and Natural Resource Management, University of Copenhagen, Denmark \\ ${ }^{\mathrm{d}}$ Department of Biology, University of Copenhagen, Denmark \\ e Department of Biology, University of Southern Denmark, Denmark \\ ${ }^{\mathrm{f}}$ Department of Marine Geology and Glaciology, Geological Survey of Denmark and Greenland, Denmark \\ ${ }^{\mathrm{g}}$ Aquatic Biology, Department of Bioscience, Aarhus University, Denmark
}

\section{A R T I C L E I N F O}

\section{Article history:}

Received 11 May 2013

Accepted 8 March 2014

Available online 18 March 2014

\section{Keywords}

diatoms

paleoecology

stable isotopes

grain size

sedimentation

Viet Nam

\begin{abstract}
A B S T R A C T
Dated sediment cores taken near the head and mouth of a tropical estuary, Nha-Phu/Binh Cang, in south central Viet Nam were analyzed for changes over time in physical, chemical and biological proxies potentially influenced by removal of the mangrove forest lining the estuary. A time-series of satellite images was obtained, which showed that the depletion of the mangrove forest at the head of the estuary was relatively recent. Most of the area was converted into aquaculture ponds, mainly in the late 1990's. The sediment record showed a clear increase in sedimentation rate at the head of the estuary at the time of mangrove deforestation and a change in diatom assemblages in the core from the mouth of the estuary indicating an increase in the water column turbidity of the entire estuary at the time of the mangrove deforestation. The proportion of fine-grained sediment and the $\delta^{13} \mathrm{C}$ signal both increased with distance from the head of the estuary while the carbon content decreased. The nitrogen content and the $\delta^{15} \mathrm{~N}$ signal were more or less constant throughout the estuary. The proportion of fine-grained material and the chemical proxies were more or less stable over time in the core from the mouth while they varied synchronously over time in the core from the head of the estuary. The sediment proxies combined show that mangrove deforestation had large effects on the estuary with regard to both the physical and chemical environment with implications for the biological functioning.
\end{abstract}

(c) 2014 Elsevier Ltd. All rights reserved.

\section{Introduction}

The area occupied globally by mangrove forests has declined by more than 35\%, and most of this loss has occurred over the past 30 years, primarily due to human disturbance (Agardy et al., 2005; Bouillon et al., 2008). Loss of mangrove forests is caused by a variety of human activities, including clearing for lumber and

* Corresponding author. Department of Plant and Environmental Sciences (PLEN), University of Copenhagen, Thorvaldsensvej 40, 1st Floor, DK-1871 Frederiksberg C, Denmark.

E-mail addresses: me@plen.ku.dk, me@bio.ku.dk (M. Ellegaard), tuonggiang82@yahoo.com (N.T.G. Nguyen), tja@ign.ku.dk (T.J. Andersen), andersm@bio.ku.dk (A. Michelsen), habviet@dng.vnn.vn (N.L. Nguyen), habsea@ dng.vnn.vn (N.H. Doan), ebk@biology.sdu.dk (E. Kristensen), kaaw@geus.dk (K. Weckström), tongphuochoangson@gmail.com (T.P.H. Son), lund-hansen@ biology.au.dk (L.C. Lund-Hansen). firewood, development of rice paddies and establishment of aquaculture ponds (Valiela et al., 2001; Wilkie and Fortuna, 2003). In many places, mangrove removal occurs without regard for the role of mangrove forests in the functioning of adjacent coastal ecosystems (e.g. Alongi, 2008). Besides the function as e.g. valuable nursery and feeding grounds for a variety of invertebrate and fish species (Hong and San, 1993), mangrove forests are key sites for important biogeochemical transformations as well as exchange of organic and inorganic carbon between land, atmosphere and ocean (Dittmar et al., 2006; Kristensen et al., 2008). This is of particular concern as mangrove forests have the potential to mitigate the effects of future climate changes (Alongi, 2008; Donato et al., 2011; Mcleod et al., 2011), both by sequestering carbon, protecting neighboring estuaries from terrestrial runoff and sheltering coastlines from storm damage, (Dahdouh-Guebas et al., 2005; Granek 


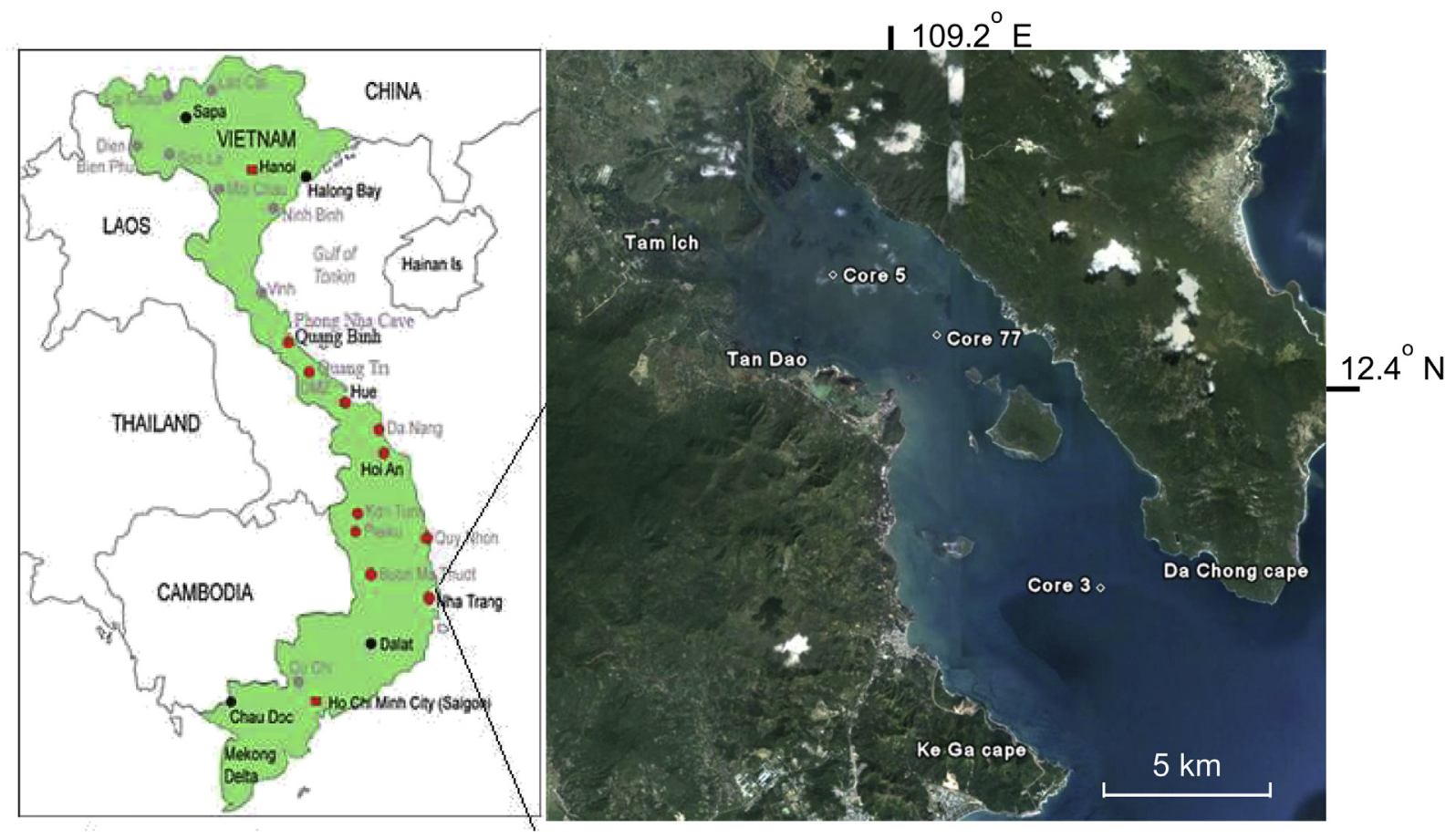

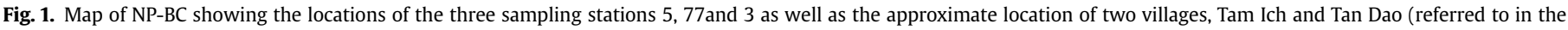
discussion)

and Ruttenberg, 2008). Viet Nam is very dependent on the functioning of its coastal ecosystems because of its approx. $3260 \mathrm{~km}$ long coastline with large areas of lowland including large delta regions in the south (Mekong Delta) and north (Red River Delta). There are over 250 large and small estuaries along the Vietnamese coast and most of these were previously lined with dense mangrove forests. However, much of this mangrove area has now been logged (Hong and San, 1993).

The Nha Phu-Binh Cang estuary (NP-BC) is located in southcentral Viet Nam. The head of this estuary was formerly covered by dense forests with dominance of the mangrove genera Rhizophora, Avicennia, and Sonneratia (Nguyen et al., 2006). However, this area and the mouths of two rivers entering the estuary are now dominated by aquaculture ponds and the mangrove forests have mostly disappeared. The exact timing of the large-scale reduction of the mangrove forest was previously unknown and the associated effects were recognized only from anecdotal evidence.

Although mangrove forests have great influence on the estuaries they line, relatively little is known about the consequences of mangrove deforestation for species distribution and ecosystem functioning of the estuaries. This study aimed at describing changes over time in physical, chemical and biological sediment parameters associated with mangrove deforestation in the NP-BC estuary by exploring the sedimentary archive at stations located at the head and mouth of the estuary. As mangrove forests often act as filters for e.g. nutrients and sediment from river run-off (Prasad and Ramanathan, 2008; Twilley and Rivera-Monroy, 2009), we would expect to see changes in e.g. terrestrial input, turbidity and nutrients. To determine such long-term developments, the parameters explored included temporal changes in sedimentation rate, grain size distribution, carbon and nitrogen content as well as stable isotope $\left(\delta^{13} \mathrm{C}, \delta^{15} \mathrm{~N}\right)$ signatures and diatom community composition. The age-depth profiles of these proxies were related to the timing of the mangrove forest disappearance and other anthropogenic activities in the area, such as constructions on the rivers entering the head of the estuary.

\section{Materials and methods}

\subsection{Site description}

The Nha Phu-Binh Cang (NP-BC) estuary is located in southcentral Viet Nam, about $15 \mathrm{~km}$ north of Nha Trang city (Fig. 1). It is about $20 \mathrm{~km}$ long and 5-6 km wide. The head of the estuary consists of a shallow area with a maximum depth of 2 whereas the mouth of the estuary at station 3 is ca. $12 \mathrm{~m}$ deep. The depth increases to more than $30 \mathrm{~m}$ within $10 \mathrm{~km}$ of the head of the estuary. Two larger rivers with a drainage area of about $1200 \mathrm{~km}^{2}$ discharge into the estuary. A base-flow of $60 \mathrm{~m}^{3} \mathrm{~s}^{-1}$ was measured in one of these rivers, the Dinh River, during the rainy season (Lund-Hansen et al., 2013). The residence time of water in the estuary is about 5-6 days (Lund-Hansen et al., 2010).

\subsection{Satellite images of mangrove distribution}

Maps of the head of NP-BC were obtained and analyzed to determine the timing of mangrove conversion into shrimp ponds. The maps were based on satellite imagery obtained from the Landsat MSS (1973 and 1983), MOS-1 (1989, 1993, and 1996), and Landsat ETM (1999) with spatial resolutions of 60,50 , and $30 \mathrm{~m}$ respectively. Four spectral bands were used from the Landsat MSS, and MOS-1, and 6 bands from the Landsat ETM. The GIS software package ENVI 4.4 was used for data processing and generation of thematic maps. A time-series of selected years between 1973 and 1999 covering the head of the estuary is used to demonstrate the changes.

\subsection{Sampling}

Three sampling stations, station 5 (12.4264 N $109.1826 \mathrm{E})$, station $77(12.4117 \mathrm{~N} 109.2089 \mathrm{E})$ and station $3(12.3500 \mathrm{~N}$ 109.2500 E), were established at the head and the mouth of the estuary. They are henceforth termed the head of the estuary (station 5 in the inner and 77 in the outer of the shallow part of the 
estuary) and the mouth of the estuary (station 3). A Kayak corer with a diameter of $83 \mathrm{~mm}$ was used to collect sediment cores in November 2009 (station 5 and 3) and November 2010 (station 77). One core from each station was sliced at $1-\mathrm{cm}$ intervals. The samples were kept in the dark at $5{ }^{\circ} \mathrm{C}$ until freeze-dried. Subsamples from all three cores were processed for ${ }^{210} \mathrm{~Pb}$ dating, while depth profiles of grain size analysis, $\mathrm{C}$ and $\mathrm{N}$ elemental concentrations and stable isotope signatures were only achieved for core 5 and 3 . These latter parameters are only included from the surface of core 77. Furthermore, subsamples from core 3 at the mouth were processed for diatom analyses.

\subsection{Sediment dating}

The freeze-dried subsamples were analyzed for ${ }^{210} \mathrm{~Pb},{ }^{137} \mathrm{Cs}$ and ${ }^{226} \mathrm{Ra}$ by gamma-spectrometry at the Gamma Dating Center at the Department of Geography and Geology, University of Copenhagen. The measurements were carried out on a Canberra low-background Ge-detector. ${ }^{210} \mathrm{~Pb}$ was measured from its gamma-peak at $46,5 \mathrm{keV}$, ${ }^{226} \mathrm{Ra}$ from the granddaughter ${ }^{214} \mathrm{~Pb}$ (peaks at 295 and $352 \mathrm{keV}$ ) and ${ }^{137} \mathrm{Cs}$ from its peak at $661 \mathrm{keV}$.

\subsection{Grain size determination}

Grain size analyses were conducted at the Centre for Geogenetics of Copenhagen University. Wet subsamples were suspended in about $10 \mathrm{ml}$ of distilled water in plastic containers. These samples were sonicated for about half an hour to break clusters and aggregates before analysis for grain size using Malvern laser Master-sizer 2000, which measures material from 0.02 to $2000 \mu \mathrm{m}$. Each sample was automatically measured 3 times to get a mean grain size distribution. Some samples showed peaks at $500-1000 \mu \mathrm{m}$. These fractions were excluded from the analyses as they were considered to be aggregates or fragments of organisms.

\subsection{Stable $C$ and $N$ isotopes}

Shell fragments and living biomass were manually removed from wet sediment before treating $1 \mathrm{~g}$ subsamples with $5 \mathrm{ml}$ of $1 \mathrm{M}$ $\mathrm{HCl}$ to dissolve particulate inorganic carbon (PIC). After freezedrying the sediment was finely ground to a homogenous powder and subsequently dry weights of $25-30 \mathrm{mg}$ were wrapped in $5 \times 9 \mathrm{~mm}$ tin capsules before combustion and EA_IRMS (elemental analysis-isotope ratios mass spectrometry) for determination of $\mathrm{C}$ and $\mathrm{N}$ elemental concentrations and isotopic values. The results are expressed as $\delta$ values in per mil units (\%) following the equation: $\delta=\left(R_{\text {sample }} / R_{\text {standard }}-1\right) \times 1000$ (Sulzman, 2008) where $R={ }^{13} \mathrm{C} /{ }^{12} \mathrm{C}$ or ${ }^{15} \mathrm{~N} /{ }^{14} \mathrm{~N}$. Tests showed that there was no substantial effect of acid treatment on $\mathrm{N}$ concentration or $\delta^{15} \mathrm{~N}$. Non-treated and treated cores showed $\mathrm{N}$ concentrations of $0.18 \%$ and $0.16 \%$ and $\delta^{15} \mathrm{~N}$ values of $5.01 \%$ and $5.47 \%$, respectively.

\subsection{Diatom analysis}

Subsamples from the core from the mouth of the estuary were prepared for diatom analysis as described by Renberg (1990) and later modified by Battarbee et al. (2001). Sediment samples were oxidized with $35 \% \mathrm{H}_{2} \mathrm{O}_{2}$ to remove organic matter. After oxidation, a few drops of $10 \% \mathrm{HCl}$ were added to remove the remaining $\mathrm{H}_{2} \mathrm{O}_{2}$ and any carbonates, and finally $10 \% \mathrm{NH}_{4}$ was used to remove minerogenic matter before making permanent slides. A volume of $400 \mu$ final sample solution was carefully pipetted on a coverslip, left to evaporate and permanent slides were made using Naphrax for fixation. Diatoms were identified using an Olympus BH2-Japan light microscope with $60 \times$ and $100 \times$ phase contrast objectives. On average 300 , and at least 100 , diatom frustules were counted per sample. Stratigraphic profiles of the diatom distribution, and of the other proxies, were created using the program C2 (Juggings, 2007).

\section{Results}

\subsection{Timing of mangrove disappearance}

The time-series of satellite images shows a progressively diminishing area of mangrove forests at the head of the estuary starting in 1973, progressing through the 1980s and accelerating in the early 1990s (Fig. 2). There was a distinct initial decline in the area covered by mangrove forest around 1983, while the major part of the mangrove forest disappeared during a period of 5 years in the mid to late 1990 s. At the same time $80 \%$ of the area presently covered by aquaculture ponds appeared (Fig. 3).

\subsection{Chronology in the cores}

The sediment from the three examined stations have very low contents of ${ }^{137} \mathrm{Cs}$ (below $6 \mathrm{~Bq} \mathrm{~kg}{ }^{-1}$ ), which renders this isotope not valuable for dating purposes in the present case. Similarly low activities were found by Frignani et al. (2007) in Tam Giang - Cau Hai lagoon in central Vietnam. They speculated that the low activity indicated a possible loss of ${ }^{137} \mathrm{Cs}$ attached to fine particles which bypass the estuary and are transported to the ocean. The activity of unsupported ${ }^{210} \mathrm{~Pb}$ in cores 5 and 77 from the head of the estuary shows high and only slightly decreasing ${ }^{210} \mathrm{~Pb}$ content in the upper 60 and $40 \mathrm{~cm}$ of the sediment, respectively. The activity of ${ }^{210} \mathrm{~Pb}$ decreased rapidly below these depths with no measurable content of unsupported ${ }^{210} \mathrm{~Pb}$ below (Fig. 4). The chronologies for the cores were calculated using a modified CRSmodel (constant rate of supply) where the inventory below 60 and $40 \mathrm{~cm}$, respectively, was calculated from a regression of unsupported ${ }^{210} \mathrm{~Pb}$ vs. accumulated mass depth. The cores indicate rapid sedimentation since 1984 (core 5) and 2000 (core 77), on top of sediment which is at least 100-120 years old as deduced from the absence of unsupported ${ }^{210} \mathrm{~Pb}$. Calculations of chronologies based on the CIC-method (Constant Initial Concentration, Appleby, 2001 ) give essentially similar results. It is of note that any sediment mixing, e.g. induced by bioturbation, will tend to increase the apparent accumulation rate in the top of the cores and the calculated sedimentation rates are therefore maximum values. Core 3 from the mouth of the estuary showed a more gradual decline in unsupported ${ }^{210} \mathrm{~Pb}$ in the upper $60 \mathrm{~cm}$, but again there is an indication of changing sedimentation at depth, although with considerable variability below $40 \mathrm{~cm}$ depth (Fig. 4). The chronology in this core was therefore calculated as outlined above with a regression in only the upper $40 \mathrm{~cm}$. Based on this chronology the upper $40 \mathrm{~cm}$ at the mouth has been deposited since 1938 (Fig. 5). Only the data for the dateable parts of each core have been included in all subsequent evaluations.

\subsection{Silt and clay contents}

There are high levels of fine-grained material at all locations in the estuary, with highest content of silt and clay $(<63 \mu \mathrm{m})$ at the mouth of the estuary (Fig. 6) and with sand contents generally below $10 \%$. The percentage of fine-grained sediment in the surface increased from around 90\% at the head to around 98\% at mouth of the estuary. The proportion of fine-grained material at the head of the estuary fluctuated with depth/age between $85 \%$ and $91-94 \%$, with lowest levels around 1978 and 1998. The proportion of fine- 

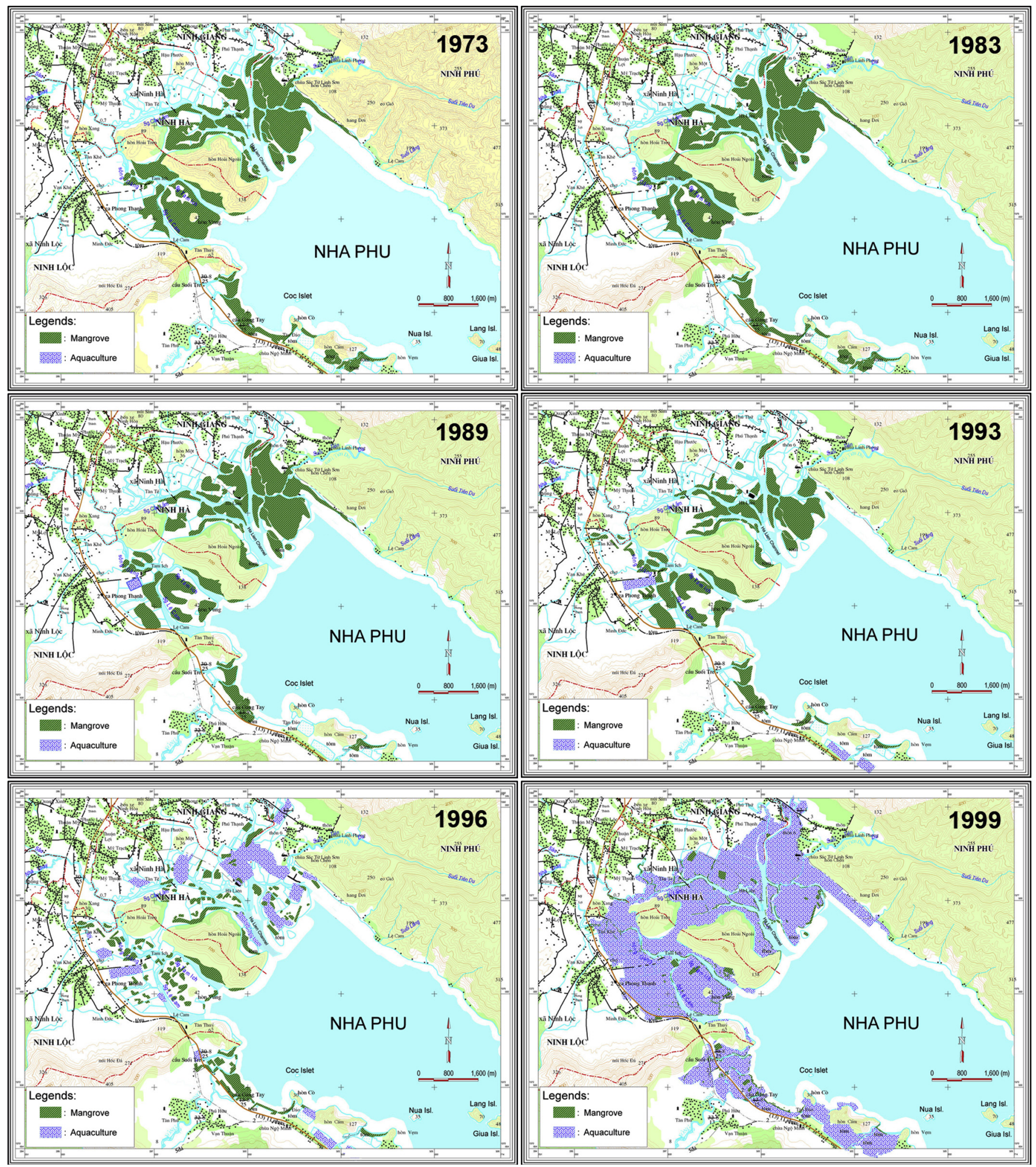

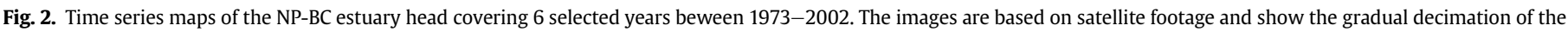

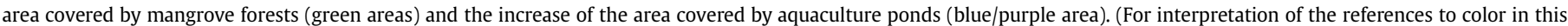
figure legend, the reader is referred to the web version of this article.)

grained material at the mouth is extremely stable at $98 \%$ from the surface of the sediment and down to the depth dated around 1973 at station 3 (Fig. 6). Below 1970 (including the un-dateable part of the core), the proportion of fine grained material fluctuated between 92 and $97 \%$.

\subsection{Profiles of carbon (C) and nitrogen $(N)$ concentrations, and stable isotope signatures}

The carbon content is higher at the head $(1.9-2.2 \%)$ than at the mouth of the estuary (1.2-1.6\%, Fig. 6). The carbon content 


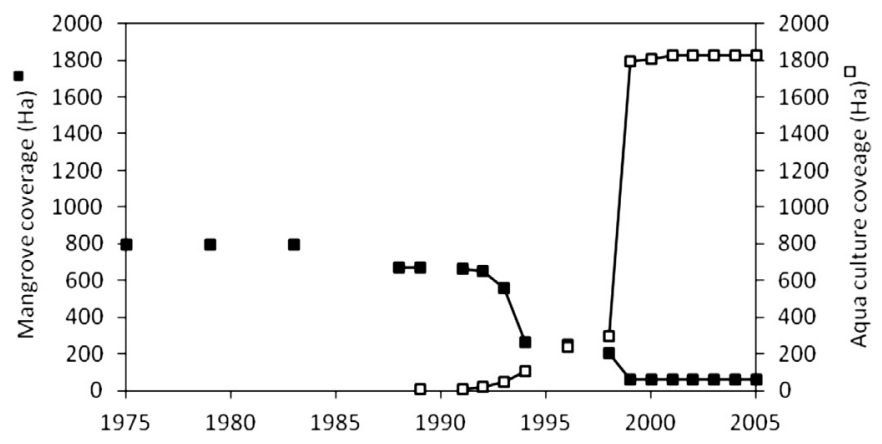

Fig. 3. The extent of the areas covered by mangrove forests and aquaculture ponds over time. Filled squares show the area of mangrove forests in hectares (left axis) and open squares the area of aquaculture ponds in hectares (right axis).

fluctuated with the lowest level around 1998 at the head, while there was a gradual decrease with depth at the mouth. The nitrogen content is relatively low and similar at both stations (0.09-0.16\%) and decreased gradually with depth even below the dateable levels (Fig. 6). Variations in both carbon and nitrogen content coincide with the variations in grain size at the head of the estuary (Fig. 6). The $\mathrm{C} / \mathrm{N}$ ratio at the head reached values as high as 17 (Fig. 6), and generally increased with depth in the sediment. Considerably lower $\mathrm{C} / \mathrm{N}$ ratios were observed at the mouth of the estuary, where it was stable at around 10 from ca. 1950 to the present, but with a slightly higher level (up to 12) deepest in the sediment.

The $\delta^{13} \mathrm{C}$ signal is lower at the head than at the mouth of the estuary. $\delta^{13} \mathrm{C}$ at the head varied from -24 to $-27 \%$ with depth in the sediment (Fig. 6). The signal at the mouth remained stable at $-22 \%$ throughout the core, even below the dateable part. The overall levels of $\delta^{15} \mathrm{~N}$ are similar at station 5 and 3, but considerably less stable with depth at the head (from 4 to $7 \%$ ) than at the mouth (from 5 to $6 \%$ ). The fluctuations in $\delta^{15} \mathrm{~N}$ at the head coincided with the fluctuations in concentration of silt and clay (Fig. 6). The values for the surface sample from core 77 in the outermost part of the head lagoon were generally between the values for the inner head and the mouth (Fig. 6).

The correlations between the percentage mud/silt and the four chemical parameters are all significant ( $p \leq 0.05$; Pearsons product moment correlation), confirming the synchronicity of the fluctuations seen in Fig. 6.

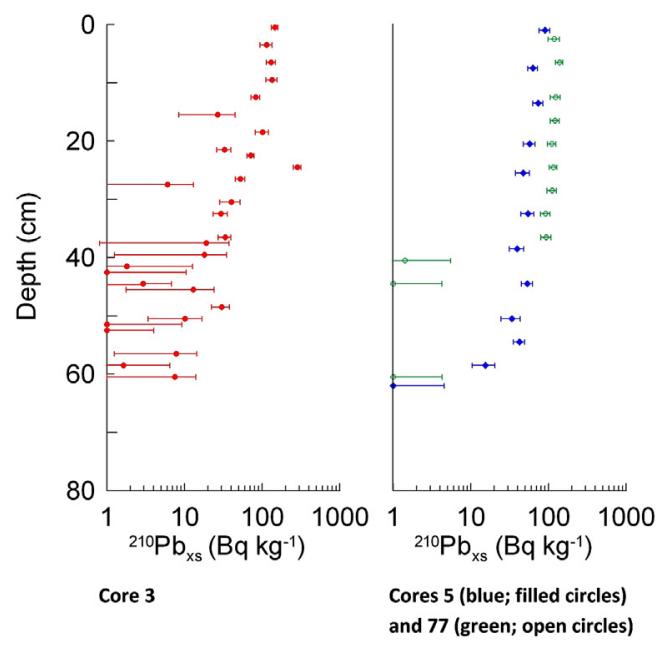

Fig. 4. The activity of unsupported ${ }^{210} \mathrm{~Pb}$ (beq $\mathrm{kg}^{-1}$ ) over depth in the cores from stations 3, 5 and 77. Left: Station 3 (red), Right Stations 5 (blue; filled circles) and 77 (green; open circles). Note the abrupt shift at ca. 60 and $40 \mathrm{~cm}$ in the cores from the head of the estuary (core 5 and 77). (For interpretation of the references to color in this figure legend, the reader is referred to the web version of this article.)

\subsection{Diatom composition}

A total of 89 diatom taxa were identified in the core from the mouth of the estuary, with 69 of them identifiable to species level and the rest to genus level (raw data in Supplementary Material). The proportion of planktonic diatoms fluctuated in the bottom part of the core, stabilized at $10-20 \%$ in the middle part of the core (ca. 1960-1985) and increased to levels around $50-80 \%$ in the top of the core (ca. 1988-2007) (Fig. 7). The dominant planktonic species in the upper part included Cyclotella striata with a maximum of $83 \%$, Paralia sulcata at $69 \%$ and Thalassionema nitzschioides at $48 \%$. The dominant benthic species in the intermediate layer was Nitzschia valdestriata with a greatest relative abundance of $89 \%$.

\section{Discussion}

\subsection{Mangrove deforestation}

The NP-BC estuary has for decades been influenced by intense anthropogenic activity in the form of intensive fishing (Strehlow, 2006), mangrove deforestation and widespread aquaculture (Table 1). The rivers running into the estuary are also influenced by human activities, notably the river Dinh on which a dam (1983) and two weirs (1968 and 1993) have been constructed (pers. comm. Doan Nhu Hai, Institute of Oceanography). According to Mazda et al. (2002), deforestation of mangrove areas in Viet Nam has occurred since the late 19th century and was caused first by development of rice paddies and then in the 20th century by herbicide action during the Viet Nam war. However, deforestation of the mangrove areas at the head of the NP-BC estuary has been quite recent, beginning ca. 1973 and intensifying in the 1990's, with the major part of the forests disappearing within a period of only 5 years from ca. 1993-1998 (Figs. 2 and 3).

\subsection{Sediment dynamics}

The amount of particulate matter input to tropical estuaries depends on various factors. Among these are land use (Carmichael and Valiela, 2005), river discharge (Umezawa et al., 2009) and not least the extent of mangrove vegetation (Furukawa et al., 1997). Much of the particulate matter entering estuaries lined with welldeveloped mangrove forests are efficiently trapped by the dense root system (Brinkman et al., 2005). If this particle trapping rootsystem disappears by deforestation, the estuary will receive a large input of suspended particles. Accordingly, the ${ }^{210} \mathrm{~Pb}$ profiles in the cores near the head of the NP-BC estuary showed recent rapid sedimentation coinciding approximately with the time of the greatest mangrove deforestation. The approx. $60 \mathrm{~cm}$ of sediment above the $\sim 1984$ dating horizon in core 5 is estimated to have been deposited within 25 years with an average rate of approx. $2.4 \mathrm{~cm} \mathrm{y}^{-1}$, whereas the sediment below $60 \mathrm{~cm}$ was deposited at least 100 years ago. In core 77, sediment accretion has been $3.6 \mathrm{~cm} \mathrm{y}^{-1}$ since 2000 , again with underlying sediment deposited at least 100 years ago. Such a rapid change in sedimentation was not evident in core 3 from the mouth of the estuary that showed a much lower and relatively uniform rate of approx. $0.55 \mathrm{~cm} \mathrm{y}^{-1}$ since 1938 (Figs. 4 and 5). This indicates that the effect of increased sedimentation was diluted or dispersed by tides and ocean currents at the mouth of the estuary. The higher content of fine-grained material near the mouth of the estuary supports the analyses by Bui (1997) indicating that coarser material is deposited rapidly near the head (Fig. 6).

The sedimentation rates given above are maximum values assuming limited biogenic particle mixing of the sediments. This seems to be a valid assumption towards the mouth where only 


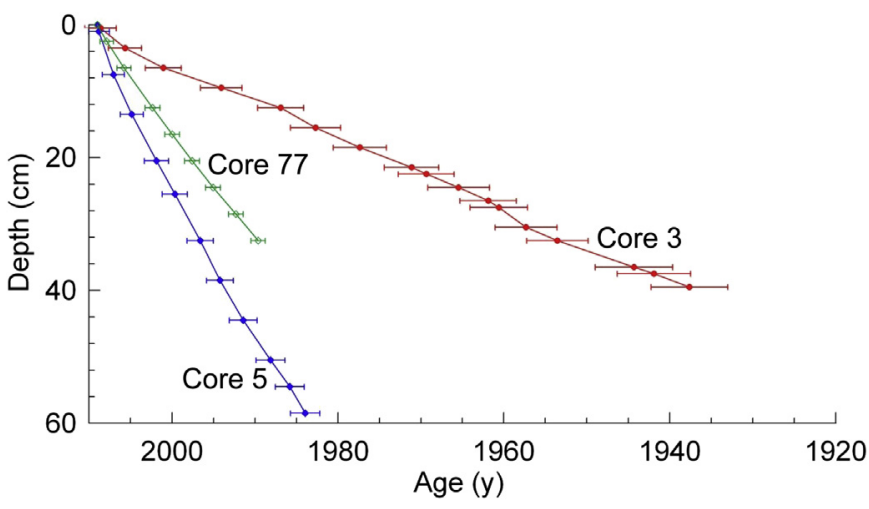

Fig. 5. Age-depth model output for the dated cores from the estuary head (cores 5; blue and 77; green) and mouth (core 3; red) based on ${ }^{210} \mathrm{~Pb}$ dating, assuming constant rate of supply of unsupported ${ }^{210} \mathrm{~Pb}$ (CRS-model). (For interpretation of the references to color in this figure legend, the reader is referred to the web version of this article.)

sparse populations of small macrofaunal species are present (Nguyen et al., 2012; pers. comm. Kurt Thomas Jensen, Aarhus University). However, numerous holes with a diameter of $2-5 \mathrm{~cm}$ were observed visually in the muddy sediment bed at the head of the estuary. These may be burrow openings formed by mantis shrimps, which are known to inhabit such sediments, forming burrows to at least $30 \mathrm{~cm}$ depth (Atkinson et al., 1997). The presence of such a vigorous bioturbator may cause an overestimation of the sedimentation rate at the head of the estuary, but it is not possible to quantify this effect because no data on particle mixing rates by mantis shrimps are available. Importantly, the indications of recent rapid sedimentation at the head of the estuary are corroborated by questionnaires to local residents in the villages around the estuary, who note a reduction in water depth at the head of the estuary (Strehlow, 2006). In this report it is stated: "... several water areas around Tam Ich that have been deeper in the past, i.e. $2.5 \mathrm{~m}$, are only $1.5 \mathrm{~m}$ deep today... In front of Tan Dao this phenomenon is even more distinct. The water that used to be more than $2 \mathrm{~m}$ deep now only measures $70 \mathrm{~cm}$...". Tam Ich is a village close to the river mouth at the southwest part of the head of NP-BC and Tan Dao is a village slightly further along the south shore in the inner part of the estuary (see Fig. 1).

Only few studies have reported sedimentation rates in tropical estuaries, but it appears that the recent rapid sediment accretion at the head of the estuary is considerably larger than typically

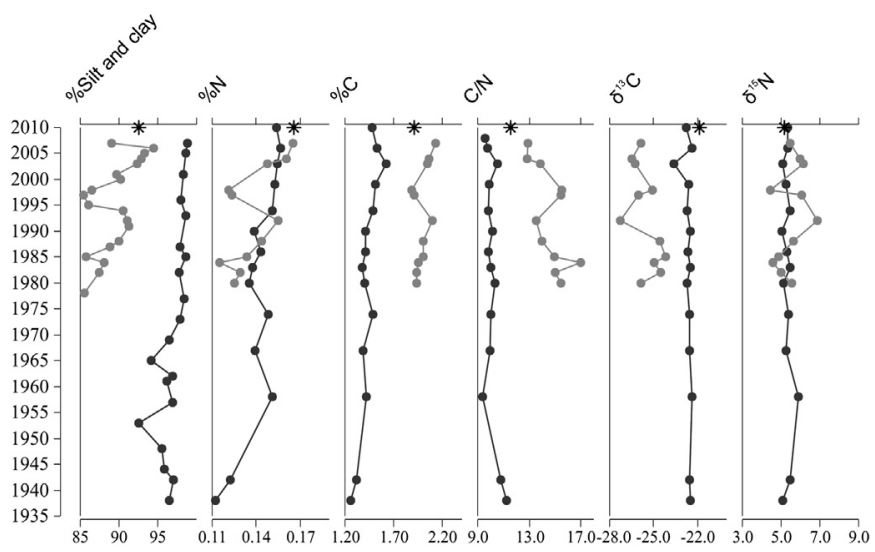

Fig. 6. Depth profiles of fine-grained material (silt and clay), $\mathrm{N}$ concentration, $\mathrm{C}$ concentration, $\mathrm{C} / \mathrm{N}$ ratios, $\delta^{13} \mathrm{C}$ and $\delta^{15} \mathrm{~N}$ signal at stations 3 (black) and 5 (gray). Surface sample values from station 77 are shown with an *. observed. For example, the sedimentation rates found at the head of the estuary are approx. 5 to 10 times higher than the $0.3-$ $0.6 \mathrm{~cm} \mathrm{y}^{-1}$ found by Frignani et al. (2007) in Tam Giang - Cau Hai lagoon in central Vietnam and 8 to 10 times higher than the rate found in the Las Matas lagoon in the Mexican gulf (Ruiz-Fernández et al., 2012). We infer that deforestation of the mangrove vegetation is the main cause for the rapid sedimentation at the head of estuary, although our rates may be overestimated due to bioturbation.

The concurrent temporal changes in the silt/clay content at the head of the estuary with changes in $\mathrm{C}$ and $\mathrm{N}$ concentrations and $\delta^{15} \mathrm{~N}$ signatures and the negative correlation with $\delta^{13} \mathrm{C}$ signatures (see Fig. 6) indicates that these parameters are all responding to the same forcing factor(s). A similar pattern was found in the Ba Lat Estuary, also in Viet Nam, where TOC and $\delta^{13} \mathrm{C}$ showed opposite patterns (Tue et al., 2011b). In Ba Lat, however, C/N and $\delta^{13} \mathrm{C}$ covaried, while their relationship is more unclear at the head of the NP-BC estuary. This pattern in Ba Lat was interpreted as being governed by diagenetic processes and a major shift in the source of organic material. Mangrove-derived debris is commonly transported into the estuaries lined with mangrove forests. This particulate organic matter feeds the estuarine food webs and will ultimately be deposited in the sediments (Jennerjahn and Ittekkot, 2002; Wolff, 2006) at an extent that varies with the distance from the mangrove vegetation and the amplitude of tidal cycles (Rezende et al., 1990). Mangrove deforestation will therefore not only impact the transport of particulate matter from land to the estuarine ecosystem, but also its composition, leading to higher deposition of silt and lower deposition of mangrove derived organic matter (Alfaro, 2010). Accordingly, the observed shifts in elemental composition of NP-BC sediments correlate with the two major periods of mangrove forest disappearance. The first small deforestation occurred around 1983-85 followed by a second and much more extensive deforestation around 1993-95. The timing of these periods also corresponds with the changes in the diatom records after 1975, with an initial increase in planktonic species in at ca. 1980 and later (ca. 1995) a total disappearance of the benthic species Nitzschia valdestriata and appearance of true planktonic taxa.

The large increase in sedimentation rate at the head of the estuary during the time of mangrove deforestation was not accompanied by an increase in the average sediment grain size. Similarly, no changes in grain size composition were observed following the construction of the dam and weir in Dinh River.

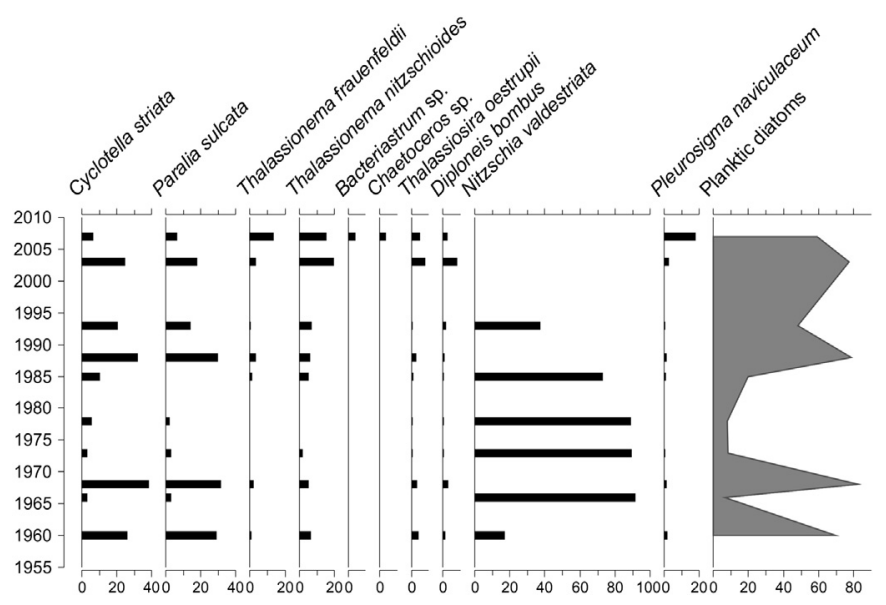

Fig. 7. Stratigraphic diagrams of changes in diatom species composition over time. Only dominant species are shown. The last panel shows the total proportion of planktonic diatoms (gray area). The remainder is the proportion of benthic diatoms. All species and raw counts can be downloaded from (Supplementary Material). 
Table 1

Timing of events in the Nha Phu-Binh Cang estuary based on core dating, satellite imagery as well as physical, chemical and biological properties of the sediment.

\begin{tabular}{lll}
\hline Approx. year & Event & Proxy responses \\
\hline 1940 & $\begin{array}{l}\text { Dating horizon at station 3 } \\
\text { Construction of first weir }\end{array}$ & Grain size shift at station 3 \\
1963 & $\begin{array}{l}\text { First signs of Mangrove cutting } \\
\text { Dating horizon at station 5 }\end{array}$ & $\begin{array}{l}\text { Initial decline in Mangrove } \\
\text { covered area }\end{array}$ \\
1980 & Construction of dam & Diatom shift \\
1983 & Construction of second weir & $\begin{array}{l}\text { Shifts in proxies } \\
\text { at station 5 }\end{array}$ \\
1985 & Maximal mangrove cutting & \\
1993 & $\begin{array}{l}\text { Maximal expansion } \\
\text { of shrimp ponds }\end{array}$ & \\
$1998-1998$ & & \\
\end{tabular}

Sediments in the estuary had organic carbon and nitrogen contents (ca. $1.5 \%$ and ca. $0.15 \%$, respectively) comparable to that found by Tue et al. (2012) for another Vietnamese estuary, but lower than most mangrove lined tropical estuaries (Bouillon and Boschker, 2006; Kristensen et al., 2008). The gradual decrease of carbon and nitrogen with depth in the sediment may indicate microbial degradation over time. Such a pattern is often observed particularly in sediments as a rather steep and leveling-off decrease in concentrations with depth, which reflects a decreasing reactivity of the organic matter with age (Canfield et al., 2005; Burdige, 2006). This is supported by the apparent preferential removal of nitrogen with depth as indicated from the gradually increased $\mathrm{C} / \mathrm{N}$ ratios, a pattern that is commonly observed in marine sediments (Canfield et al., 2005). However, the continued decrease observed here also suggests that an overall increase in organic deposition may have occurred over time. Trinh et al. (1979) actually found that in 1976 organic carbon and nitrogen content in NP-BC surface sediments varied between 1.75 and $0.07 \%$ and between 0.18 and $0.015 \%$, respectively. The levels found in the present study are higher than that for both carbon and nitrogen, suggesting that nutrient levels, and thus pelagic primary production, indeed were lower three decades ago and that the decrease in organic matter with depth may indicate changes in organic deposition over time combined with post-depositional biogeochemical modifications.

\subsection{Stable isotopes}

The stable carbon isotope signature, $\delta^{13} \mathrm{C}$, is a reliable indicator for the source of organic matter (Sweeney et al., 1978; Andrews et al., 1998). Thus, a $\delta^{13} \mathrm{C}$ signal close to $-5 \%$ may indicate that the organic material is predominantly of marine origin while a signal near $-30 \%$ refers to organic material of predominantly terrestrial or mangrove (C3 plant) origin. Accordingly, Tue et al. (2011a) reported a $\delta^{13} \mathrm{C}$ value of $-28.3 \%$ or mangrove leaves from a Vietnamese estuary. The generally increasing $\delta^{13} \mathrm{C}$ signal in the sediments from ca. $-26 \%$ at the head to ca. $-22 \%$ at the mouth of the estuary, indicates a change in organic matter input from terrestrial to marine origin towards the mouth of the estuary, which is independent of mangrove deforestation (Fig. 6). Tue et al. (2011a) similarly reported a gradient in $\delta^{13} \mathrm{C}$ from $-25.4 \%$ in the upper reaches to $-21.2 \%$ at the mouth of a mangrove-lined estuary. The $\delta^{13} \mathrm{C}$ signal is almost completely stable throughout the examined sediment depth at the mouth of the estuary, while the signal fluctuates at the head of the estuary, possibly associated with changes in the intensity of mangrove deforestation, as explained in Section 4.2. The conclusion by Pham (1981) that $70 \%$ of the sediment in NP-BC is terrestrially derived is confirmed by the low $\delta^{13} \mathrm{C}$ signals found at the head of the estuary in the present study.
In contrast to the other sediment parameters in the NP-BC estuary, there are no spatial differences in the $\delta^{15} \mathrm{~N}$ signal. The $\delta^{15} \mathrm{~N}$ signature of mangrove-derived material does not systematically deviate from that of marine production (Bouillon et al., 2008), and is therefore not a valid indicator of the organic source, but is merely used to determine trophic levels in food chains. The $\delta^{15} \mathrm{~N}$ signature of primary producers is controlled by the isotopic value of their $\mathrm{N}$ source, the temporal and spatial variation in $\mathrm{N}$ availability, and changes in their demand (Dawson et al., 2002). However, elevated $\delta^{15} \mathrm{~N}$ values have been recorded from urbanized areas exposed to sewage-derived eutrophication (Cole et al., 2004; Bannon and Roman, 2008). Accordingly, no strong sewage influence is apparent at the head of the NP-BC lagoon, as indicated by the similar and relatively low levels of $\delta^{15} \mathrm{~N}$. Nevertheless, the fluctuating signal with depth at the head of the estuary may, together with the pattern of other parameters, be driven by erratic changes in sewage influence coinciding with the disappearance of the mangrove forest and other anthropogenic activities.

\subsection{Changes in diatom community}

Diatoms can be valuable indicators of water quality, since they are sensitive to changes in the environment regarding e.g. nutrient status, turbidity/light, temperature, salinity and $\mathrm{pH}$ (Smol and Stoermer, 2010). The dominant diatom species in this study are cosmopolitan taxa with broad ecological tolerances commonly found in coastal areas. Hence the indicator value of the individual species is limited. However, there are clear changes in diatom lifeforms in the sediment record, which can illustrate past changes at the study site. The most marked shift in the diatom community occurred ca. 1985 from a predominantly benthic community to dominance by planktonic species. Shifts from benthic to planktonic diatom communities are often driven by increased turbidity in the water, leading to reduced light penetration (Cooper and Brush, 1991; Weckström et al., 2007 and references therein) caused by either high phytoplankton biomass (following increased nutrient levels) or by high suspended sediment load in the water column (following mangrove deforestation). The shift in diatom community composition in NP-BC (Fig. 7) may be instigated by either of these factors or by a combination. The slight increasing trend in nitrogen concentration through time may have increased the phytoplankton biomass, but it is more likely that the shift is caused mainly by the increased amount of fine-grained sediment load entering the estuary since the mangrove forest removal. Recent studies have shown relatively low settling velocities of suspended material in the estuary (Andersen et al., 2014) causing a permanent and high turbidity when the sediment loading is high. It is therefore likely that the observed shift from predominantly benthic to planktonic diatoms is primarily driven by the removal of the mangrove forest. The periodic shifts between the benthic Nitzschia valdestriata and the (tycho)planktonic Cyclotella striata and Paralia sulcata in the diatom record prior to the mangrove deforestation are probably also caused by changes in turbidity due to other unknown perturbations. However, these shifts in diatom community composition in the bottom part of the core differ from the large shift in species composition coinciding with the main mangrove deforestation, when true planktonic diatom taxa become more abundant.

\subsection{Main conclusions}

Overall, the sediment core proxies show both a distinct horizontal gradient in the estuary and clear temporal changes, coinciding with the timing of mangrove deforestation, with consequences both for the physical and chemical properties as well 
as biological structure of the estuary (exemplified by the diatom community).

1. There are clear signs of increased sedimentation at the head of the estuary during and after the time of mangrove disappearance.

2. The sediment in NP-BC is dominated by fine particles both now and in the past, with temporal variability at the head of the estuary.

3. The variability in grain size distribution over time at the head of the estuary, with concurring shifts in $\mathrm{C}$ and $\mathrm{N}$ content, as well as $\delta^{13} \mathrm{C}$ and $\delta^{15} \mathrm{~N}$ may be linked to variability in the intensity of mangrove deforestation.

4. Relatively low contents of $\mathrm{C}$ and $\mathrm{N}$ and low $\delta^{13} \mathrm{C}$ signals indicate that the estuary is not greatly organically enriched and that the material in the estuary is predominantly of terrestrial (and mangrove) origin, although gradually mixed with more marine material near the mouth.

5. The diatom assemblage shows indications of increased turbidity in the water after ca. 1985, most likely caused by increased supply of fine grained material to the estuary after the disappearance of the mangrove forest and/or an increase in primary productivity in the estuary, driven by increased $\mathrm{N}$ levels.

\section{Acknowledgments}

This study was part of the project ClimeeViet "Climate Change and Estuarine Ecosystem in Viet Nam" (CLIMEEViet) funded by DANIDA-Fellowship Center under project code "P2-08-Vie".

\section{Appendix A. Supplementary data}

Supplementary data related to this article can be found at http:// dx.doi.org/10.1016/j.ecss.2014.03.007.

\section{References}

Agardy, T., Alder, J., Dayton, P., Curran, S., Kitchingman, A., Wilson, M., Catenazzi, A. Restrepo, J., Birkeland, C., Blaber, S., Saifullah, S., Branch, G., Boersma, D., Nixon, S., Dugan, P., Davidson, N., Vörösmarty, C., 2005. Coastal Systems. UN Millennium Ecosystem Assessment (Chapter 19), pp. 513-548.

Alfaro, A.C., 2010. Effects of mangrove removal on benthic communities and sediment characteristics at Mangawhai Harbour, northern New Zealand. ICES J. Mar Sci. 67, 1087-1104.

Alongi, D.M., 2008. Mangrove forests: resilience, protection from tsunamis, and responses to global climate change. Estuar. Coast Shelf Sci. 76, 1-13.

Andersen, T.J., Markussen, T.N., Heidemann, R., Lund-Hansen, L.C., Nielsen, M.H. Hai, D.N., Ellegaard, M., Lam, N.N., 2014. Flocculation in the water column or aggregation at the bed? Nha Phu Estuary. Vietnam. Ocean Sciences Meeting, 23-28 February 2014. Hawaii, USA. Abstract ID: 16439.

Andrews, J.E., Greenaway, A.M., Dennis, P.F., 1998. Combined carbon isotope and C/N ratios as indicators of source and fate of organic matter in a poorly flushed, tropical estuary: hunts Bay, Kingston Harbour, Jamaica. Estuar. Coast Shelf Sci. 46, 743-756

Appleby, P.G., 2001. Chronostratigraphic techniques in recent sediments. In: Last, W.M., Smol, J.P. (Eds.), Tracking Environmental Change Using Lake Sediments, Basin Analysis, Coring and Chronological Techniques, vol. 1. Kluwer Academic Publishers, the Netherlands.

Atkinson, R.J.A., Frogliae, C., Arneri, E., Antolini, B., 1997. Observations on the burrows and burrowing behaviour of Squilla mantis (L.) (Crustacea: Stomatopoda). P.S.Z.N. Mar. Ecol. 18, 337-359.

Bannon, R.O., Roman, C.T., 2008. Using stable isotopes to monitor anthropogenic nitrogen inputs to estuaries. Ecol. Appl. 18, 22-30.

Battarbee, R.W., Jones, V.J., Flower, R.J., Camerons, N.G., Bennion, H., 2001. Diatoms In: Smol, J.P., Birks, H.J.B., M.Last, W. (Eds.), Tracking Environmental Change Using Lake Sediments, Terrestrial, Algal, and Siliceous Indicators, vol. 3. Kluwer Academic Publishers, Dordrecht, the Netherlands.

Bouillon, S., Boschker, H.T.S., 2006. Bacterial carbon sources in coastal sediments: a cross system analysis based on stable isotope data of biomarkers. Biogeosciences 3, 175-185.

Bouillon, S., Connolly, R.M., Lee, S.Y., 2008. Organic matter exchange and cycling in mangrove ecosystems: recent insights from stable isotope studies. J. Sea Res. 59, 44-58.
Brinkman, R., Wattayakorn, G., Wolanski, E., Spagnol, S., Marshall, K., 2005. Stormdriven erosion of fine sediment and its subsequent transport and trapping in fringing mangroves, Sawi Bay, Thailand. J. Coast Res. 42, 211-220.

Bui, H.L. (Ed.), 1997. Investigation of the Environmental Status and Marine Resources in NhaPhu - BinhCang (KhanhHoa). Institute of Oceanography. Unpublished research (in Vietnamese), $150 \mathrm{pp}$.

Burdige, D.J., 2006. Geochemistry of Marine Sediments. Princeton University Press, New Jersey, 609 pp.

Canfield, D.E., Kristensen, E., Thamdrup, B., 2005. Aquatic Geomicrobiology. Academic Press.

Carmichael, R.H., Valiela, I., 2005. Coupling of near-bottom seston and surface sediment composition: changes with nutrient enrichment and implications for estuarine food supply and biogeochemical processing. Limnol. Oceanogr. 50, 97-105.

Cole, M.L., Valiela, I., Kroeger, K.D., Tomasky, G.L., Cebrian, J., Wigand, C., McKinney, R.A., Grady, S.P., da Silva, M.H.C., 2004. Assessment of a delta N-15 isotopic method to indicate anthropogenic eutrophication in aquatic ecosystems. J. Environ. Qual. 33, 124-132.

Cooper, S.R., Brush, G.S., 1991. Long-term history of Chesapeake Bay anoxia. Science 254, 992-996.

Dahdouh-Guebas, F., Jayatissa, L.P., Di Nitto, D., Bosire, J.O., Lo Seen, D., Koedam, N., 2005. How effective were mangroves as a defence against the recent tsunami? Curr. Biol. 15, 1337-1338.

Dawson, T.E., Mambelli, S., Plamboeck, A.H., Templer, P.H., Tu, K.P., 2002. Stable isotopes in plant ecology. Annu. Rev. Ecol. Syst. 33, 507-559.

Dittmar, T., Hertkorn, N., Kattner, G., Lara, R.J., 2006. Mangroves, a major source of dissolved organic carbon to the oceans. Glob. Biogeochem. Cycles 20, GB1012.

Donato, D.C., Kauffman, J.B., Murdiyarso, D., Kurnianto, S., Stidham, M., Kanninen, M., 2011. Mangroves among the most carbon-rich forests in the tropics. Nat. Geosci. Lett. 4, 293-297. NGEO1123.

Frignani, M., Piazza, R., Bellucci, L.G., Cu, N.H., Zangrando, R., Albertazzi, S., Moret, I., Romano, S., Gambaro, A., 2007. Polychlorinated biphenyls in sediments of the Tam Giang-Cau Hai Lagoon, Central Vietnam. Chemosphere 67, 1786-1793.

Furukawa, K., Wolanski, E., Mueller, H., 1997. Currents and sediment transport in mangrove forests. Estuar. Coast Shelf Sci. 44, 301-310.

Granek, E.F., Ruttenberg, B.I., 2008. Changes in biotic and abiotic processes following mangrove clearing. Estuar. Coast Shelf Sci. 80, 555-562.

Hong, P.N., San, H.T., 1993. Mangroves of Vietnam. IUCN Bangkok, Thailand, pp.1-173.

Jennerjahn, T.C., Ittekkot, V., 2002. Relevance of mangroves for the production and deposition of organic matter along tropical continental margins. Naturwissenschaften 89, 23-30.

Juggings, S., 2007. C2 Data Analysis v.1.5.1.Computer Program. Department of Geography, University of Newcastle, UK.

Kristensen, E., Bouilllon, S., Dittmar, T., Marchand, C., 2008. Organic carbon dynamics in mangrove ecosystems: a review. Aquat. Bot. 89, 201-219.

Lund-Hansen, L.C., Hai, D.N., Lam, N.N., Nielsen, M.H., 2010. Optical properties of a tropical estuary during wet and dry conditions in the Nha Phu Estuary, Khanh Hoa Province, south-east Vietnam. Hydrobiologia 644, 207-216.

Lund-Hansen, L.C., Nielsen, J., Blüthgen, J., Hai, D.N., Nielsen, M.H., Lam, N.H., 2013. Estuarine morphometry governs optically active substances, $\mathrm{K}_{\mathrm{d}}(\mathrm{PAR})$ and beam attenuation: assessment from a tropical ria and a temperate coastal plain estuary. Hydrobiologia. http://dx.doi.org/10.1007/s10750-013-1457-1.

Mazda, Y., Magi, M., Nanao, H., Kogo, M., Miyagi, T., Kanazawa, N., Kobashi, D., 2002. Coastal erosion due to long-term human impact on mangrove forests. Wetl. Ecol. Manag. 10, 1-9.

Mcleod, E., Chmura, G.L., Bouillon, S., Salm, R., Björk, M., Duarte, C.M., Lovelock, C.E., Schlesinger, W.H., Silliman, B.R., 2011. A blueprint for blue carbon: toward an improved understanding of the role of vegetated coastal habitats in sequestering $\mathrm{CO}_{2}$. Front. Ecol. Environ. 9, 552-560.

Nguyen, N.L., Nguyen, T.M.A., Doan, N.H., Ho, V.T., 2006. Phytoplankton in Nha Phu lagoon, Viet Nam. In: Selection of Marine Research Work, vol. 15. Inst. of Oceanography, Science and Technique Publishing House, Hanoi, Viet Nam, pp. 117-135 (in Vietnamese, with English abstract).

Nguyen, H.K., Kristensen, E., Lund-Hansen, L.C., 2012. Benthic metabolism and nitrogen transformations affected by fish cage farming in the tropical Nha Phu estuary (Vietnam). Mar. Freshw. Res. 63, 887-897.

Pham, V.T., 1981. Surface Sediment of Coastal Waters of PhuKhanh Province. In: Selection of Marine Research Work, vol. 2. Inst. of Oceanography, Science and Technique Publishing House, Hanoi, Viet Nam, pp. 179-188 (in Vietnamese, with English abstract).

Prasad, M.B.K., Ramanathan, A.L., 2008. Sedimentary nutrient dynamics in a tropical estuarine mangrove ecosystem. Estuar. Coast Shelf Sci. 80, 60-66.

Renberg, I., 1990. A procedure for preparing large sets of diatom slides from sediment cores. J. Paleolimnol. 4, 87-90.

Rezende, C.E. Lacerda, L.D., Ovalle, A.R.C., Silva, C.A.R., Martinelli, L.A., 1990. Nature of POC transport in a mangrove ecosystem: a carbon stable isotopic study. Estuar. Coast Shelf Sci. 30, 641-645.

Ruiz-Fernandez, A.C., Sprovieri, M., Piazza, R., Frignani, M., Sanchez-Cabeza, J.A. Feo, M.L., Belluci, L.G., Vecchiato, M., Perez-Bernal, L.H., Paez-Osuna, F., 2012. $\mathrm{Pb}-210$-derived history of PAH and PCB accumulation in sediments of a tropical inner lagoon (Las Matas, Gulf of Mexico) near a major oil refinery. Geochim. Cosmochim. Acta 82, 136-153.

Smol, J.P., Stoermer, E.F., 2010. The Diatoms: Applications for the Environmental and Earth Sciences. Book 686 pp.. Cambridge University Press. 
Strehlow, H.V., 2006. Integrated natural resources management of coastal fisheries. In: The Case of Nha Phu Lagoon, Vietnam. Unpublished PhD thesis.

Sulzman, E.W., 2008. Stable isotope chemistry and measurement: a primer. In: Michener, R., Lajtha, K. (Eds.), Stable Isotopes in Ecology and Environmental Science, second ed.

Sweeney, R.E., Liu, K.K., Kaplan, I.R., 1978. Oceanic nitrogen isotopes and their use in determining the sources of sedimentary nitrogen. In: Robinson, B.W. (Ed.), Stable Isotopes in the Earth Sciences, Bulletin 220. Department of Scientific and Industrial Research, Wellington, pp. 9-26.

Trinh, P., Pham, V.T., Nguyen, T.S., Trinh, T.H., Tran, H., Tran, D.T., Nguyen, H.S., 1979. Geomorphological and Sedimentological characteristics in BinhCang - NhaPhu Bay. Collect. Mar. Res. 1, 77-92 (in Vietnamese, with English abstract).

Tue, N.T., Hamaoka, H., Sogabe, A., Quy, T.D., Nhuan, M.T., Omori, K., 2011a. Sources of sedimentary organic carbon in mangrove ecosystems from Ba Lat Estuary, Red River, Vietnam. In: Omori, K., Guo, X., Yoshie, N., Fujii, N., Isobe, I.C., Tanabe, S. (Eds.), Interdisciplinary Studies on Environmental Chemistry - Marine Environmental Modeling and Analysis, pp. 151-157.

Tue, N.T., Hamaoka, H., Sogabe, A., Quy, T.D., Nhuan, M.T., Omori, K., 2011b. The application of $\delta^{13} \mathrm{C}$ and $\mathrm{C} / \mathrm{N}$ ratios as indicators of organic carbon sources and palaeoenvironmental change of the mangrove ecosystem from Ba Lat Estuary, Red River, Vietnam. Environ. Earth Sci. 64, 1475-1486.
Tue, N.T., Ngoc, N.T., Quy, T.D., Hamaoka, H., Nhuan, M.T., Omori, K., 2012. A crosssystem analysis of sedimentary organic carbon in the mangrove ecosystems of Xuan Thuy National Park, Vietnam. J. Sea Res. 67, 69-76.

Twilley, R.R., Rivera-Monroy, V.H., 2009. Ecogeomorphic models of nutrient biogeochemistry for mangrove wetlands. In: Perillo, G.M.E., Wolanski, E., Cahoon, D.R., Brinson, M.M. (Eds.), Coastal Wetlands: an Integrated Ecosystem Approach. Elsevier.

Umezawa, Y., Komatsu, T., Yamamuro, M., Koike, I., 2009. Physical and topographic factors affecting suspended particulate matter composition in a shallow tropical estuary. Mar. Environ. Res. 68, 59-70.

Valiela, I., Bowen, J.L., York, J.K., 2001. Mangrove forests: one of the world's threatened major tropical environments. Bioscience 51, 807-815.

Weckström, K., Korhola, A., Weckström, J., 2007. Impacts of eutrophication on diatom life forms and species richness in coastal waters of the Baltic Sea. Ambio $36,155-160$.

Wilkie M.L, Fortuna, S, 2003 Status and Trends in Mangrove Area Extent Worldwide. Forest Resources Assessment Working Paper No. 63. FAO, Rome.

Wolff, M., 2006. Biomass flow structure and resource potential of two mangrove estuaries: insights from comparative modeling in Costa Rica and Brazil. Rev. Biol. Trop. 54 (Suppl. 1), 69-86. 